\title{
The Impact Covid-19 Pandemic on Productivity of Tax Return Document Processing in the New Normal Era at Tax Data and Document Processing Center
}

\author{
Pri Budiarti Rini Sejati \\ APN (S2) Politeknik STIA LAN Jakarta \\ Email: pbrinis1@gmail.com
}

(Received: October 24-2020; revised: November 24-2020; published: December 31-2020)

\begin{abstract}
This study aims to determine the impact of the Covid-19 Pandemic on the productivity of documents in the New Normal Era at Tax Data and Document Processing Center. This type of research is a descriptive study, with a research focused by analyzing the production of Tax Return document processing before and after the Covid-19 pandemic. The Purpose of this scientific article is to provide a new view to the State Civil Service that the normal era is a pushing factor or trigger for future organizational management innovation. The method used in this study is a qualitative approach. Data collection was carried out through direct interviews with employees in the Taxation Data and Document Processing Center. The key informants in this study were employees of the Document Collection and Receiving Section and the Recording and Data Transfer Section. This study shows that there were changes in behavior and habits at work such as lessening work days due to the Work From Office and Work From Home policies leading to a significant decrease in the productivity of Tax Return document processing. The higher number of employees and work days (as well as work hours/day) in office the higher number of processed Tax Return documents. The number of Tax Return documents processing in the new era is normal has significant decreased due to limited human resources available in office and decreasing work days.
\end{abstract}

\section{Keywords: Covid-19 Pandemic, Productivity, Processing, Tax Return, New Normal Era}

\section{INTRODUCTION}

The ongoing Corona Disease 2019 pandemic (Covid-19) spreading in almost whole countries in the world, including Indonesia has given impacts on economic, social, cultural, health, education, etc. According to Wiktionary, an impact is a strong influence that has consequences (both negative and positive), whereas in Wikipedia, the definition of the Covid-19 Pandemic is an event of the spread of Coronavirus 2019 (Covid-19) around the world. The disease is caused by a new type of coronavirus, named SARS-CoV-2. The first case was identified in Wuhan City, Hubei Province, China on December 1, 2019, and was declared a pandemic by the World Health Organization (WHO) on 11 March 2020. Up to 17 September 2020, more than $29,864,555$ cases have been reported in more than 210 countries and territories worldwide, resulting more than 940,651 deaths and more than 20,317,519 people get well. To overcome the problems new social life consisting new norms and rules was proposed. Now we live in a new normal era. In the new normal era people do their activities while at the same time they have to obey health protocols such as wearing a mask, washing hands with soap and flowing water and physical distancing.as well as keeping adequately healthy nutrition intake and physical exercise. In working area organizational structure and management should be adaptive to ongoing situation. 
Pri Budiarti Rini Sejati; The Impact Covid-19 Pandemic on Productivity of Tax Return ... $\mid 475$

Before entering the new normal era, Government Regulation number 21 of 2020 concerning Large-Scale Social Restrictions in the context of the Acceleration of Handling Corona Disease 2019 Covid -19) It has been stipulated that the PSBB is carried out, one of which is by closing the workplace. However restrictions of work activities could not be imposed forever. Economy has to run as usual. Minister of Health said that business and work activities should be given more attention considering big number of workers (employees) with their intensive mobility could be a major transmitter for virus of Covid -19 disease (SARS Cov-2 virus). Office and other workplaces as a melting point should be a focus in mitigating Covid -19 disease.

In the new normal era there is a need to adapt new condition of work. Changes in structural and management of work activities including in government office are unavoidable. To face the challenge innovation in managing human resources with more flexibility is carried out. Such efforts are also done by the Directorate General of Taxes (DJP). However due to Covid-19 pandemic processing of documents-19 was also affected. This paper will oversee impact of Covid-19 pandemic on productivity of Tax Return document processing in the New Normal Era at Tax Data and Document Processing Center.

\section{METHOD}

The method used in this study is a qualitative approach. Data collection was carried out through direct interviews with employees in the Taxation Data and Document Processing Center. The key informants in this study were employees of the Document Collection and Receiving Section and the Recording and Data Transfer Section. The research methodology is a way to find data validation of thought critical for seeking knowledge of something in order to find something new. To this research method used is a qualitative method. Creswell (2017) states that Research qualitative itself are methods to explore and understand the meaning by a number an individual or group of people ascribed to humanity or from social problems. Process This qualitative research involves a number of important efforts e.g. asking questions and procedures, gathering specific data from participants, inductively analyzing data starting from various specific themes to common themes, and interpret the meaning of the data. The final report of this research have a flexible structure or framework. Anyone who participated in this form of research must carry out an inductive-style research perspective, focusing on undividual meanings and translating the complexity of the problem (adapted from Cesswell, 2007).

Martono (2016) states that qualitative research produces data in recorded form of interview results, interview transcripts, notes on observations, various written documents, and notes others who were not recorded during data collection, Miles and Huberman (1994) as quoted by Martono (2016) stated that the qualitative data analysis process includes four important processes, namely (1) data reduction (2) data presentation (3) verification (4) data collection. Data reduction is a process of selection, simplifying, abstracting, and modifying raw data from written records generated while in the field and the process is ongoing. Presentation of data is the activity of presenting research data, thus allowing researchers to take temporary conclusions, then planning further action either there is still incomplete data or needs clarification or the data is already complete. Verification is an activity to formulate conclusions while or final or final conclusion on the basis of the two previous activities. 


\author{
476 | Jurnal Ilmiah Ilmu Administrasi Publik: Jurnal Pemikiran dan Penelitian Administrasi \\ Publik \\ Volume 1o Number 2, July-December 2020. Page 474-481
}

Creswell (2007) states that in qualitative research, data collection activities, analyzing data, and compiling reports is not a process that must be carried out sequentially, Qualitative research always reflects on the data findings obtained. Neuman (2018) stated that Descriptive research is research whose main objective is to provide an overview with words, numbers, and to present the profile (problem), classification of types and outline of stages to answer questions, for example who, when, where, and how. The research was carried out by technical data collection, namely interviews and observations and review of documents. Interviews were conducted for validate the various documents available and gather in-depth information.

The temporary conclusion was that there were changes in behavior and habits at work such as lessening work days due to the Work From Office and Work From Home policies that caused a significant decrease in the productivity of Tax Return document processing.

\title{
RESULTS AND DISCUSSION
}

The SARS-CoV-2 virus is thought to spread between people primarily through respiratory droplets (droplets) produced during coughing. These splashes can also result from sneezing and normal breathing. Virus can contaminate an object and stay there a certain time. Hands that touched the contaminated object could be a transmitter. Therefore people have to clean their hands before touching face. SARS Cov-2 virus that causes COVID-19 disease is contagious. With or without symptoms people who suffer Covid - 19 disease could transmit the virus. The virus will incubate in human body from one to fourteen days, usually around five days. Efforts to prevent the spread of the corona virus are carried out such as travel restrictions, quarantine, enforcement curfew, delay and cancellation of events, and closure of facilities. The office clusters have appeared since the beginning of the new normal era. More and more employees being assigned to WFH.

Working from home will provide flexible time and life balance for workers (employees), on the other hand also provides benefits for the company, however work from home is not easy to do in Tax Data and Document Processing Center where employees work with paper based documents. Physical processing of Tax Return documents can only be done in the office because Tax Return documents are confidential. The processing is assisted by a system, namely the Kofax Total application Ability application (KTA) and supporting applications.

This physical processing of documents is regulated in Circular number SE-25/PJ/2018 concerning Follow-up on Tax Returns Received at the Taxation Data and Document Processing Unit. Below is a list of packaged picks affected by the WFO and WFH policies. As for Tax Return document processing in 2019 amounted to 9.2 million, while for 2020 it is estimated at 5.8 million as more Taxpayers report electronically (e-filing).

After collecting and receiving documents, the Tax Return document processing is carried out from sorting, scanning, document review, validation, and repacking to quality assurance of processing and document storage, but in this research processing Tax Return documents from paper into this digitization is limited to repacking only that directly related to physical documents. For production processing of Tax Return documents for Java and Madura during the PSBB Period as in table 1 below: 
Pri Budiarti Rini Sejati; The Impact Covid-19 Pandemic on Productivity of Tax Return ... $\mid 477$

\section{Table 1 TAX RETURN DOCUMENT PROCESSING PRODUCTION REGION IN THE TIME OF PSBB}

\begin{tabular}{llcccccc}
\hline No & Description & \multicolumn{6}{c}{ Production (thousands of pieces) } \\
\cline { 3 - 8 } & & \multicolumn{2}{c}{ March } & \multicolumn{2}{c}{ April } & \multicolumn{2}{c}{ May } \\
\cline { 3 - 8 } & & $\mathbf{2 0 1 9}$ & $\mathbf{2 0 2 0}$ & $\mathbf{2 0 1 9}$ & $\mathbf{2 0 2 0}$ & $\mathbf{2 0 1 9}$ & $\mathbf{2 0 2 0}$ \\
\hline $\mathbf{1}$ & Sort & 977,39 & 532,14 & $1.468,54$ & 0 & $2.181,85$ & 0 \\
\hline $\mathbf{2}$ & Scan & 790,01 & 673,68 & $1.523,82$ & 0 & $1.966,74$ & 0 \\
\hline $\mathbf{3}$ & $\begin{array}{l}\text { Document } \\
\text { review }\end{array}$ & 726,72 & 580,89 & $1.556,78$ & 0 & 2.060 .82 & 13,59 \\
\hline $\mathbf{4}$ & Validation & 655,26 & 677,51 & 1.506 .75 & 0 & $2.026,82$ & 16,67 \\
\hline $\mathbf{5}$ & Repack & 549,32 & 716,38 & 1.398 .34 & 0 & 1.910 .72 & 48,27 \\
\hline
\end{tabular}

Source: Final Report on the Progress of Work Results for November 2019

Report on the Progress of Work Implementation Results for September 2020

\section{Information:}

1. Sort is the sorting of documents to be scanned

2. Scan is scanning a document and will be an image

3. Document review is the arrangement of the document scan results

4. Validation is the recording of physical documents

5. Repack is the repacking of the Tax Return after the document is scanned

In table 1, Number of document processing during the PSBB Period has decreased significantly because the WFO policy which allow only $25 \%$ of total number of employees work in office starts on the 3rd week of March 2020. Since April 2020 there was not production at all because no single one Tax Return document taking from the Tax Office. In May 2020 the documents which were processed come from the rest of works in the previous months and document package from Borneo. For the production of document processing for Java and Madura in the New Normal Era as in table 2 below:

\section{Table 2 TAX RETURN DOCUMENT PROCESSING PRODUCTION JAVA AND MADURA REGION IN THE NORMAL ERA (PSBB TRANSITION)}

\begin{tabular}{llcccccccc}
\hline \multirow{2}{*}{$\begin{array}{l}\text { N } \\
\text { o. Description }\end{array}$} & \multicolumn{9}{c}{ Production (thousands of pieces) } \\
\cline { 3 - 10 } & & \multicolumn{2}{c}{ June } & \multicolumn{2}{c}{ July } & \multicolumn{2}{c}{ August } & \multicolumn{2}{c}{ September } \\
\cline { 3 - 10 } & & $\mathbf{2 0 1 9}$ & $\mathbf{2 0 2 0}$ & $\mathbf{2 0 1 9}$ & $\mathbf{2 0 2 0}$ & $\mathbf{2 0 1 9}$ & $\mathbf{2 0 2 0}$ & $\mathbf{2 0 1 9}$ & $\mathbf{2 0 2 0}$ \\
\hline 1 & Sort & $1.407,35$ & 417,22 & $1.641,11$ & $1.063,37$ & $1.081,53$ & 427,57 & 224,19 & 550,77 \\
\hline 2 & Scan & $1.417,33$ & 376,65 & $1.704,05$ & $1.112,09$ & $1.187,57$ & 466,39 & 318,13 & 581,23 \\
\hline 3 & $\begin{array}{l}\text { Document } \\
\text { review }\end{array}$ & $1.410,98$ & 316,6 & $1.798,58$ & $1.010,51$ & 1.233 .10 & 413,11 & 322,73 & 702,12 \\
& & & & & & & & \\
\end{tabular}




\section{8 | Jurnal Ilmiah Ilmu Administrasi Publik: Jurnal Pemikiran dan Penelitian Administrasi Publik \\ Volume 10 Number 2, July-December 2020. Page 474-481}

\begin{tabular}{rlllllllll}
\hline 4 & Validation & $1.428,51$ & 314,15 & $1.688,16$ & 954,12 & $1.491,64$ & 327,9 & 392,31 & 811,50 \\
\hline 5 & Repack & $1.350,34$ & 237,34 & $1.696,39$ & 323,87 & $1.112,99$ & 347,4 & 642,32 & 759,43 \\
\hline \multicolumn{7}{c}{ Source: Final Report on the Progress of Work Results for November 2019 } \\
\multicolumn{7}{c}{ Report on the Progress of Work Implementation Results for September 2020 }
\end{tabular}

In table 2 Number of document processing in the New Normal Era (Transitional PSBB) has decreased because of less number of documents to process and existing WFO policy. The percentage fluctuates, except in September 2020. In September 2020 the percentage increased due to catch up processing target by adding 30 minutes of working hours every working day from 07.00 until 16.30

According to Simanjuntak (1985), employee work productivity is influenced by several factors, namely internal factors or from the employees themselves or externally or from the company and policies government as a whole, such as education, skills, discipline, attitudes, motivation, nutrition and health, level of income or wages, means of production, climate and work environment. Government has a focus to keep people including workers (employees) healthy moreover in the time of Covid-19 pandemic. Government imposed health protocols such as wearing mask, washing hands with soap and flowing water and doing physical distancing (In Indonesia such practices is called by $3 \mathrm{M}$ ). Sanctions will be given to people who disobey health protocols. Health protocols are also applied in government office such in Tax Data and Document Processing Center that is in charge of processing documents.

According to Article 1 of Law number 28 of 2007 concerning the Third Amendment to Law number 6 of 1983 concerning General Provisions and Tax Procedures, Tax is a contribution compulsory to the state which is owed by an individual or entity which is compelling based on Law, with no direct compensation and used for state purposes for the greatest prosperity of the people, while a Tax Return is a letter that is obligatory Taxes are used to report the calculation and / or payment of taxes, tax objects and /or not tax objects, and / or assets and liabilities in accordance with statutory provisions taxation

Tax Data and Document Processing Center started operating based on the Minister of Finance Regulation number 84/PMK.01/2007 concerning Organization and Work Procedure of Taxation Data and Document Processing Center as amended with the Minister of Finance Regulation number 176/PMK.01/2019 concerning Amendments to the Ministerial Regulation! Finance Number 167/PMK.01/2016 concerning Organization and Administration of the Data Processing Center and Taxation Documents and in accordance with their duties, Tax Data and Document Processing Center will carry out the receipt, scanning, recording and storage of tax documents by utilizing information based technology laws and regulations. The implementation of this task will be carried out in stages for the type of letter notifications processed and the number of KPP that become the working area of Tax Data and Document Processing Center. and in the its development has undergone a very significant change for processing Tax Return documents, namely consisting of priority Tax Return (Annual Tax Return of Corporate Income Tax/Form1771 and Annual Tax Return of Personal Income Tax /Form 1770) Form 1770 S, 1770 
Pri Budiarti Rini Sejati; The Impact Covid-19 Pandemic on Productivity of Tax Return ... 479

SS, Periodic Tax Return of Value Added Tax (VAT), Periodic tax income of Article 21/26, Periodic tax income of Article 23/26.

In processing physical Tax Return documents, the Document Collection and Receiving Section among them tasked with sorting Tax Return documents originating from the Tax Service Office (KPP) whether the packaging was taken or sent, after that it is sent to the Document Scanning Section, namely the document is scanned in the form of an image and reviewed the scan results, after completion of the Tax Return is repacked (repack), then by the Section Recording, the scan results are recorded.

The work areas and types of Tax Return processed by Tax Data and Document Processing Center in 2019 are as follows:

\begin{tabular}{|c|c|c|}
\hline Unit Work & $\begin{array}{c}\text { Number of Regional Tax } \\
\text { Offices Work }\end{array}$ & Type of Tax Return processed \\
\hline PPDDP*) & $\begin{array}{l}\text { - } 197 \text { Tax Service Offices } \\
\text { within Regional office of } \\
\text { the Directorate General } \\
\text { of Taxes } \\
\text { - } 23 \text { Tax Service Offices } \\
\text { within Regional office of } \\
\text { the Directorate General } \\
\text { of Taxes in Borneo }\end{array}$ & $\begin{array}{l}\text { - Periodic Tax Return of Value Added } \\
\text { Tax (VAT) } \\
\text { - Annual Tax Return of Personal } \\
\text { Income Tax (Form 1770, } 1770 \text { S dan } \\
\text { 1770 SS) } \\
\text { - Annual Tax Return of Corporate } \\
\text { Income Tax (Form 1771) } \\
\text { - Periodic tax income of Article } 21 / 26 \\
\text { - Periodic tax income of Article } 23 / 26\end{array}$ \\
\hline
\end{tabular}

*) Tax Data and Document Processing Center

In accordance with the Decree of the Director General of Taxes number KEP-164/PJ/2018 concerning Determination of Tax Service Offices and Types of Tax Return Processed in Application of The Working Area of Tax Data and Document Processing Center and in 2020 the process includes Income Tax Article 15, Income Tax Article 4 paragraph (2), and Income Tax Article 22.

Based on the Decree of the Governor of DKI Jakarta number 337 of 2020 dated 20 March 2020 concerning Determination of Outbreak Disaster Emergency Response Status (Covid-19) in the Special Region Province The capital city of Jakarta. This status starts from March 20 to April 2 , 2020. Several rules, sanctions and other information related to the determination of the PSBB status for all locations in DKI Jakarta. Apart from that, application call of the Governor of DKI Jakarta number 6 of 2020 dated March 20, 2020 concerning Temporary Suspension Office Activities to Prevent the Spread of the Corona Virus Disease (Covid-19) Outbreak in DKI Jakarta Province

Minister of Empowerment of State Apparatus and Bureaucratic Reform issued a Circular number 58 of 2020 dated 29 May 2020 concerning the Work System of State Civil Servants in the New Norms and number 67 of 2020 dated 4 September 2020 concerning Amendments to Ministerial Circular Ministry of Administrative and Bureaucratic Reform Number 58 of 2020 concerning The Work System for State Civil Servants in the New Norms where the percentage of employees is regulated who work in an office (Work From Office) of 25\%, 50\%, 75\%, and 100\% based on risk zoning data issued by the Covid-19 Handling Task Force. Execution of those 


\author{
480 Jurnal Ilmiah Ilmu Administrasi Publik: Jurnal Pemikiran dan Penelitian Administrasi \\ Publik \\ Volume 1o Number 2, July-December 2020. Page 474-481
}

regulations are given to each Regional Governments respectively. In Jakarta Governor Regulation number 80 of 2020 concerning Implementation Large-Scale Social Restrictions During the Transition Period Towards a Healthy, Safe, and Productive Society 19 August 2020, namely the Extension of the PSBB prolonged again until 11 October 2020. According to the Decree of the Governor of DKI Jakarta number 959 of 2020 dated 11 September 2020 regarding the Enforcement of Large-Scale Social Restrictions in Handling Corona Virus Disease 2019 (Covid19) in DKI Jakarta Province, every work activities must be comply with health protocols to prevent the transmission of the Covid-19 virus in work places or offices.

The Ministry of Finance issued a Circular number SE-30/MK.1/2020 July 20, 2020 concerning Travel Requirements for Employees and Follow-up Work Systems in the framework of the Prevention of Corona-Virus Disease 2019 (Covid-2019) during the Transition Period in a Normal Order New in the Ministry of Finance Environment-. Then the Directorate General of Taxes issued a Circular Director General of Taxes number SE-30 / PJ / 2020 dated May 27, 2020 concerning Work Implementation Guidelines from the Office (Work From Office) and Work from Home (Work From Home) in the Prevention Period Spread of Corona Virus Disease 2019 (Covid-2019) in the Directorate General of Taxes and Letters Circular of the Director General of Taxes number SE-33 / PJ / 2020 dated June 5, 2020 concerning General Guidelines Implementation of Tasks in a New Normal Order within the Directorate General of Taxes. Based on things. Therefore, the Head of Tax Data and Document Processing Center implements WHO and WFH policies starting on the $3^{\text {rd }}$ week of March 2020 until now, only the percentage varies according to the policies of the DKI Jakarta Government.

In 2020, the number of documents processed was reduced compared to in 2019, but the types of Tax Return processed have increased coupled with the Covid-19 pandemic situation of course affect the productivity of document processing as in tables 1 and 2 concerning production document processing because this work can only be done in the office, while PPDDP also adheres to it WFH policy because it must comply with local government regulations.

\title{
CONCLUSION
}

Based on the results of the observations and discussions that have been described, the authors conclude:

The number of employees and of work days (as well as work hours/day) in office play a very important role because they work paper based documents. Supporting by a system called by KTA they do paper based documents digitizing. The higher number of employees and work days (as well as work hours/day) in office the higher number of processed Tax Return documents. The number of Tax Return documents processing in the new era is normal has significant decreased due to limited human resources available in office and decreasing work days (or work hours/day).

\section{Recommendation}

It is necessary to rearrange schedule of WFO and WFH to fit work condition (for example type and volume of works) so that productivity can be maintained optimally while health protocols are also fulfilled. 
Pri Budiarti Rini Sejati; The Impact Covid-19 Pandemic on Productivity of Tax Return ... $\mid 481$

\section{REFERENCE}

Creswell, John W., (2017). Research Design Pendekatan Kualitatif, Kuantitatif, dan Mixed. Yogyakarta, Pustaka Pelajar.

Gisela Adio Ros Maria et al., (2020). Analisis Pengaruh Peningkatan Jumlah Masyarakat Terkonfirmasi Covid-19 terhadap Produktivitas Penduduk yang Bekerja di Jabodetabek. Jurnal Pekerjaan Sosial, 3 (1), 1-15.

Intan Novela QA. (2020). Pengaturan Kerja Fleksibel Era New Normal. Diakses dari https://investor.id/opinion/pengaturan-kerja-fleksibel-era-new-normal

Keputusan Direktur Jenderal Pajak nomor KEP-164/PJ/2018 tentang Penetapan Kantor Pelayanan Pajak dan Jenis Surat Pemberitahuan yang diolah dalam rangka Penerapan Wilayah Kerja Pusat Pengolahan Data dan Dokumen Perpajakan dan Kantor Pengolahan Data dan Dokumen Perpajakan.

Keputusan Gubernur DKI Jakarta nomor 337 Tahun 2020 tanggal 20 Maret 2020 tentang Penetapan Status Tanggap Darurat Bencana Wabah (Covid-19) di Wilayah Provinsi Daerah Khusus Ibu Kota Jakarta.

Martono, Nanang, (2016). Metode Penelitian Sosial Konsep-konsep Kunci. Jakarta. PT Raja Grafindo Persada.

Neuman, W. Lawrence, (2018). Metodologi Penelitian Sosial: Pendekatan Kualitatif dan Kuantitatif. Jakarta. PT Indeks Permata Puri Media.

Peraturan Pemerintah nomor 21 Tahun 2020 tentang Pembatasan Sosial Berskala Besar dalam rangka Percepatan Penanganan Corona Disease 2019 (Covid-19).

Rokom. (2020). Pencegahan Covid-19 di Tempat Kerja Era New Normal. Diakses dari sehatnegeriku.kemkes.go.id/baca/rilis-media/20200523/5133951/pencegahan-covid-19-tempatkerja-era-new-normal/

Simanjuntak, Payaman J. (1985). Pengantar Ekonomi Sumber Daya Manusia. Jakarta: LPFE UI. hlm 74 .

Siti Hadijah. (2020). PSBB DKI Jakarta Resmi Diberlakukan, Cek Aturan Pembatasan Biar Tenang. Diakses dari https://www.cermati.com/artikel/psbb-dki-jakarta-resmidiberlakukan-cek-aturan-pembatasan-biar-tenang

Undang-undang nomor 28 Tahun 2007 tentang Perubahan Ketiga atas Undang-undang nomor 6 Tahun 1983 tentang Ketentuan Umum Dan Tata Cara Perpajakan. 